\title{
Andżelika Kuźnar
}

Szkoła Główna Handlowa w Warszawie

e-mail: andzelika.kuznar@sgh.waw.pl

\section{KRAJE GRUPY WYSZEHRADZKIEJ W GLOBALNYCH LAŃCUCHACH WARTOŚCI}

\section{THE VISEGRAD GROUP COUNTRIES IN GLOBAL VALUE CHAINS}

DOI: $10.15611 /$ pn.2017.498.16

JEL Classification: F12, F14, F15

Streszczenie: Kraje Grupy Wyszehradzkiej nie stanowią jednolitej struktury, lecz są konstruktem stworzonym przez USA i na potrzeby USA. Więzi handlowe między krajami Grupy są stosunkowo małe, a konwergencja ekonomiczna, która następuje, jest pochodną upodabniania struktur gospodarczych w ramach UE. Tym, co może zbliżyć analizowane państwa, jest ich uczestnictwo w globalnych łańcuchach wartości. Celem artykułu jest ocena zaangażowania Polski, Czech, Słowacji i Węgier oraz poszczególnych branż w globalnych łańcuchach wartości. Szczegółowej analizie poddano powiązania państw Grupy w górę i dół globalnych łańcuchów wartości oraz udział zagranicznej wartości dodanej w eksporcie brutto. Zbadano także wzajemny udział wartości dodanej z krajów V-4 w ich eksporcie. Analiza obejmuje lata 1995-2011 i opiera się na danych WTO i OECD. Wyniki wskazują na zaangażowanie krajów V-4 w umiędzynarodowieniu procesów produkcyjnych oraz rosnące między nimi więzi w tym zakresie.

Słowa kluczowe: globalne łańcuchy wartości, handel wartością dodaną, Grupa Wyszehradzka.

Summary: The Visegrad Group countries do not constitute a single structure, but they are a construct created by the US and for the US. Trade ties between the countries of the group are relatively small, and the economic convergence that takes place results from the growing similarity of economic structures within the EU. What can bring the analyzed states closer to each other is their participation in global value chains (GVC). The aim of the article is to assess the involvement of Poland, the Czech Republic, Slovakia and Hungary in GVC. Their backward and forward participation in GVC was analysed as well as the share of foreign value added in gross exports. The mutual involvement of the countries in their exports was also examined. The analysis covers the years 1995-2011 and is based on TiVa database. The results indicate growing involvement of $\mathrm{V}-4$ in the internationalization of production processes and increasing trade ties between them in this respect.

Keywords: global value chains, trade in value added, Visegrad Group. 


\section{Wstęp}

Grupa Wyszehradzka nie stanowi jednolitej struktury, lecz jest konstruktem stworzonym przez USA i na potrzeby USA. Więzi handlowe między krajami Grupy są stosunkowo małe, a konwergencja ekonomiczna, która następuje, jest wtórna w stosunku do upodobnienia struktur gospodarczych w ramach UE. Tym, co może zbliżyć analizowane państwa, jest ich uczestnictwo w globalnych łańcuchach wartości. Celem artykułu jest ocena zaangażowania Polski, Czech, Słowacji i Węgier oraz poszczególnych branż w globalnych łańcuchach wartości. Szczegółowej analizie poddano powiązania krajów Grupy w górę i dół globalnych łańcuchów wartości oraz udział zagranicznej wartości dodanej w ich eksporcie brutto. Zbadano także wzajemny udział wartości dodanej z krajów V-4 w ich eksporcie.

\section{Grupa Wyszehradzka, czyli ,bandera przed handlem"1}

Za datę powstania Grupy Wyszehradzkiej przyjmuje się 15.02.1991 r., dzień, w którym w Wyszehradzie prezydenci: Wałęsa (Polski), Havel (Czechosłowacji) i Antall (Węgier), podpisali deklarację wskazującą na cele i warunki współpracy². Jest to jednak mistyfikacja polityczna mająca sugerować samosprawczość. W rzeczywistości Grupa Wyszehradzka była (i pozostaje) amerykańskim konstruktem peryferycznym ${ }^{3}$ o charakterystyce nieprzepuszczalnej [Ash 1999]. Ten konstrukt był wynikiem sposobu postrzegania w polityce zagranicznej USA przestrzeni, na którą składały się zwasalizowane państwa byłego bloku wschodniego. Upadek ZSRR i całego bloku wschodniego z jednej strony obniżył (a wręcz zlikwidował) globalne zagrożenie strategiczne dla USA i aliantów, z drugiej zaś wytworzył zagrożenie niestabilnością w przestrzeni zarządzanej przez ZSRR jako policjanta [Engelberg 1991]. Chcąc antycypująco odeprzeć nowe zagrożenie, USA postanowiły powielić zmodyfikowany projekt OEEC i zachęcić państwa Europy Środkowej i Wschodniej do współpracy w strukturze subregionalnej (szerzej patrz: [Schmidt 2016]). Współpraca ta miała zaowocować wytworzeniem nowego regionu geopolitycznego złożonego z państw respektujących w stosunkach wewnętrznych i międzynarodowych wartości zachodnie, jednocześnie nienależących (i nieprzyjmowanych) do instytucji zachodniej hemisfery4.

\footnotetext{
${ }^{1} \mathrm{~W}$ ramach tego (geopolitycznego) podejścia potencjał państwa wpływa na gospodarkę. Szerzej: [Baru 2012].

${ }^{2}$ Declaration on Cooperation between the Czech and Slovak Federal Republic, the Republic of Poland and the Republic of Hungary in Striving for European Integration, http://www.visegradgroup. eu/documents/visegrad-declarations/visegrad-declaration-110412-2 (10.08.2017).

${ }^{3}$ Pojęcie konstruktu do nauki wprowadził G. Kelly. Zgodnie z jego teorią, konstrukt jest sposobem postrzegania lub oddziaływania na rzeczywistość. Konstrukt peryferyczny oznacza element konstruktu nadrzędnego, który nie ma dla niego charakteru podstawowego i może być zmieniony bez destrukcji konstruktu nadrzędnego. Konstrukt nieprzepuszczalny nie przyjmuje nowych elementów [Kelly 1955].

${ }^{4}$ Ani USA (w przypadku NATO), ani główne państwa członkowskie Wspólnot Europejskich (a następnie UE) nie dopuszczały myśli o admisji wskazanych państw do tych instytucji.
} 
Taki jednolity region jednak nie powstał. Do Grupy przypisano państwa połączone wyłącznie bliskością geograficzną - państwa sąsiedzkie. Nie cechowały się one jednak bliskością historyczno-kulturową i gospodarczą̧. W wymiarze politycznym członkami Grupy są: Polska, uznająca się za zwycięzcę w I wojnie światowej, o czym świadczy odzyskanie państwowości, i Węgry, uznające się za największą ofiarę tejże wojny, pozbawione Traktatem z Trianon większości terytorium zamieszkiwanego przez Węgrów. Węgry i Czechy współtworzyły państwo Austro-Węgry, Polska była podzielona pod zaborami. W trakcie II wojny światowej Polska i Czechy były ofiarami nazistowskiej agresji - członkami koalicji, zaś Słowacja i Węgry - uczestnikami sojuszu militarno-politycznego, na którego czele stała III Rzesza. Również przeszłość w stosunkach wewnętrznych i wzajemnych ma ciemne karty, z którymi państwa Grupy nie potrafią się do końca rozliczyć. Słowacja pod prezydenturą księdza Tiso była gorliwym współpracownikiem nazistów w realizacji Zagłady ${ }^{6}$. Polska wzięła udział w agresji na Czechosłowację, anektując Zaolzie. Czechy są drugim (po Estonii) najbardziej zlaicyzowanym państwem w Europie ${ }^{7}$, podczas gdy 87,2\% procent obywateli Polski deklaruje się jako katolicy (z tego 86,9\% rzymscy katolicy). Blisko Polski jest Słowacja z 62\% katolików, 8,2\% protestantów i 3,8\% grekokatolików. Od tych wskaźników odbiegają Węgrzy, wśród których 37,2\% deklaruje katolicyzm (dodatkowo 1,8\% to grekokatolicy), 13,8\% protestantyzm (większość kalwinizm) [CIA The World Factbook].

W wymiarze gospodarczym skrajności wyznaczały: Czechosłowacja - przed II wojną światową nowoczesna gospodarka przemysłowa (wyżej rozwinięta niż w Belgii), i Polska - gospodarka rolnicza ewoluująca ku gospodarce rolniczo-przemysłowej [Broadberry, Klein 2011]. Po II wojnie światowej w ramach bloku wschodniego tzw. kooperacja socjalistyczna i specjalizacja nie miały doprowadzić do równoważenia i symbiozy gospodarek, lecz do wytworzenia struktury kolonialnej typu „szprychy - piasta”, w której półkolonie są związane z ZSRR, przez który przebiegają wszystkie nitki. Gospodarki państw Grupy nie były powiązane w łańcuchy. Po 1989 r. Czechosłowacja (Czechy i Słowacja), Polska i Węgry podjęły współpracę z Zachodem, nie szukając możliwości współpracy wzajemnej. Zawarte w 1992 r. Środkowoeuropejskie Porozumienie o Wolnym Handlu (CEFTA) było warunkiem koniecznym negocjacji z UE. Obecna konwergencja Grupy jest konwergencją pochodną, tzn. akcesja do UE wytwarza spójność jej członków. Tak więc upodabnia-

${ }^{5}$ Skrajnie różny pogląd przedstawiony jest na portalu polskiego MSZ. Jednak stwierdzenie na temat Grupy, której członków „łączy nie tylko sąsiedztwo i podobne uwarunkowania geopolityczne, ale przede wszystkim wspólna historia, tradycja, kultura oraz wartości" nie zawiera uzasadnienia (http:// www.msz.gov.pl/pl/polityka_zagraniczna/europa/grupa_wyszehradzka/). Podobnie na różnice wskazuje Klus [2015].

${ }^{6}$ Problemu słowackiej hierarchii katolickiej nie należy ograniczać do Tiso, był on bowiem członkiem partii ludackiej (Słowackiej Partii Ludowej), kierowanej przez księdza Hlinkę; szerzej patrz: [Krawczyk 2015].

${ }^{7}$ Wg danych z 2011 r. 10,4\% Czechów deklaruje katolicyzm, 1,1\% protestantyzm, a 34,5\% - ateizm. 
jący się do „starej Europy” członkowie Grupy siłą rzeczy upodabniają się również do siebie 8 .

Współpraca między członkami Grupy zawsze kulała, państwa nie współpracowały ze sobą, lecz konkurowały, co było szczególnie widoczne w ich drodze do członkostwa w UE i NATO. Tocząc negocjacje równoległe, członkowie nie byli lojalni względem siebie. Alternatywą dla Grupy bez Polski była Inicjatywa Czterostronna (Quadragonale), a następnie Pentagonale, których Polska się obawiała, widząc w nich wehikuł mogący wprowadzić do struktur Zachodu wybrane państwa EŚiW, zaś Włochy i Austria widziały możliwość budowy bloku.

Tym, co obecnie różni członków Grupy jest polityka. Polska i Węgry są w ostrym konflikcie z instytucjami UE z powody zarzutów systematycznego naruszania europejskich wartości. Węgry prowadzą politykę prorosyjską i te sympatie podziela Zeman - prezydent Czech. Słowacja pod rządami populisty Fico deklaruje przywiązanie do unijnych wartości i instytucji ${ }^{9}$.

Amerykański konstrukt polityczny, jakim było utworzenie Grupy, nie miał podstaw ani gospodarczych, ani w sferze woli politycznej czterech tworzących go państw. W tym przypadku „bandera” wyprzedzała więc „handel”" W kolejnych częściach artykułu sprawdzam, czy i w jakim stopniu 25 lat później nastąpiło wyrównanie ,linii handlu” (czy szerzej geoekonomii) z „,banderą”, tzn. czy i w jakim zakresie powstały realne, gospodarcze więzi w ramach Grupy Wyszehradzkiej.

\section{Fragmentacja globalnych łańcuchów wartości}

Nowe procesy zachodzące w gospodarce światowej wymuszają poszukiwanie nowych metod ich badania i opisu. Jednym z takich procesów jest fragmentacja produkcji, czyli jej podział pomiędzy coraz liczniejsze podmioty i lokalizacje [Jones, Kierzkowski 2001]. Produkcja przedsiębiorstw ulega umiędzynarodowieniu, firmy nie wymieniają już tylko gotowych produktów, lecz ,handlują zadaniami” (trade in tasks), które mają charakter zarówno produkcyjny, jak i usługowy [Grossman, Ros-

\footnotetext{
${ }^{8}$ Patrz wystąpienie J. Hahna (komisarza UE odpowiedzialnego za politykę regionalną) w trakcie konferencji: The Visegrád Group - Growth Engine of Europe, http://ec.europa.eu/regional_policy/ upload/documents/Commissioner/Speech-Visegrad-4-Ministerial-meeting-on-Cohesion_24062014. $\operatorname{pdf}(11.08 .2017)$.

${ }^{9}$ Patrz wypowiedzi premiera Fico w trakcie konferencji prasowej 15.08.2017: „Slovakia should be part of a deeply integrated »core« European Union driven by Germany and France [...]. The fundamentals of my policy are being close to the (EU) core, close to France, to Germany [...]. I am very much interested in regional cooperation within the Visegrad Four but Slovakia's vital interest is the EU”, oraz polski tekst: http://forsal.pl/swiat/unia-europejska/artykuly/1064519,fico-chce-by-slowacja-nalezala-do-trzonu-unii-europejskiej.html (12.08.2017).

${ }^{10}$ Relacja więzi politycznych do handlowych (,handel-bandera”) jest zweryfikowanym naukowo narzędziem analizy geoekonomicznej i geopolitycznej. Por. np. [Pollins 1989, s. 465-480; Caves 2002, s. 19 i n.; van Bergeijk 2009, s. 1 i n.].
} 
si-Hansberg 2006]. Gospodarki krajów stają się coraz bardziej zintegrowane z globalnymi łańcuchami wartości (global value chains - GVC) [Gereffi 2005].

W świecie sprzed globalizacji ${ }^{11}$ każdy kraj musiał wytwarzać wszystko to, co jego mieszkańcy chcieli konsumować (ze względu na koszty transportu). Wynalazek maszyny parowej i jej zastosowanie w transporcie morskim i kolejowym (rewolucja przemysłowa) sprawiły, że produkcja i konsumpcja mogły zostać rozdzielone. Baldwin [2011] uważa, że było to pierwsze w historii globalizacji rozdzielenie procesu produkcji i konsumpcji (unbundling). Kraje mogły zacząć specjalizować się w produkcji zgodnie z posiadanymi przewagami komparatywnymi. Pojawiły się nadwyżki produkcji, które można było sprzedawać za granicę (wcześniej możliwości konsumpcyjne ograniczały wielkość produkcji), zaś niskie koszty w połączeniu z możliwościami transportu umożliwiały (zyskowną) produkcję na wielką skalę. Paradoksalnie, ponieważ taka produkcja jest skomplikowanym przedsięwzięciem, które wymaga koordynacji i jest obciążona dużym ryzykiem, występowała tendencja do skupiania wszystkich procesów produkcji w jednej fabryce lub przynajmniej w bliskiej odległości (klastry, okręgi przemysłowe) (rys. 1).
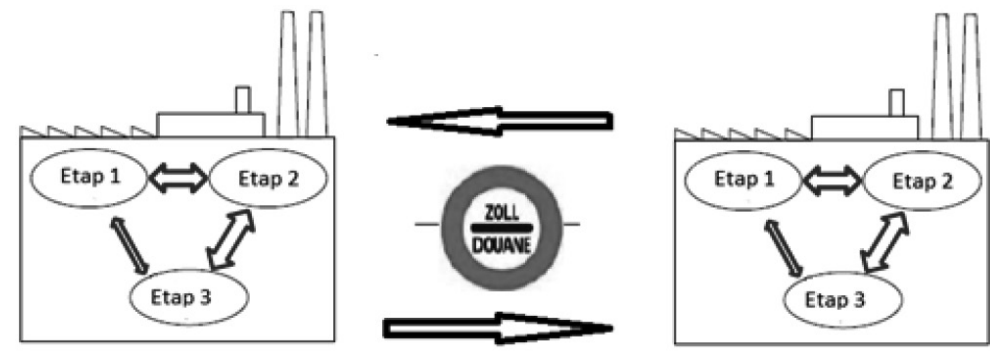

Rys. 1. Schemat ilustrujący handel międzynarodowy od końca XIX do połowy XX wieku Źródło: opracowanie własne na podstawie [Baldwin 2011].

Wraz ze spadkiem kosztów telekomunikacji i wzrostem dostępności technologii informatycznych (rewolucja informatyczna) koszty i ryzyko koordynacji produkcji spadają. Pojawiła się - również łatwiejsza w koordynacji - produkcja modułowa ${ }^{12}$. W efekcie pojawiła się możliwość przestrzennego rozdzielenia procesu produkcji pomiędzy położone w różnych krajach filie korporacji oraz podmioty niepowiązane

${ }^{11}$ Za początek globalizacji, rozumianej jako międzynarodowa integracja rynków towarowych, kapitałowych, uznaję połowę XIX w.

${ }^{12}$ Modułowość zastosowaną w produkcji można określić jako łatwość, z jaką poszczególne moduły (elementy złożone) mogą być oddzielone i łączone bez naruszania integralności produktu. Modułowość oznacza również, że elementy produktu lub procesu mogą być wykonywane niezależnie w różnych organizacjach gospodarczych, a następnie składane przez montownię z przewidywalnym skutkiem, http://www.logistyka.net.pl/bank-wiedzy/logistyka/item/7831-strategia-zakupow-modulowych-napotrzeby-produkcji (2.08.2017). 
kapitałowo i organizacyjnie (outsourcing). Baldwin [2011] uważa, że wówczas nastąpiło drugie w historii globalizacji rozdzielenie produkcji i konsumpcji. Pojawiły się możliwości zyskownego połączenia technologii krajów wysoko rozwiniętych z (niżej opłacanymi) pracownikami w krajach rozwijających się. Konsekwencją są zmiany w handlu światowym. O ile do połowy XX wieku powszechnie eksportowane były głównie dobra finalne, produkowane w całości w jednym kraju (i zawierające wkład siły roboczej, kapitału, wiedzy tego jednego kraju), o tyle handel od drugiej połowy XX wieku oznacza nieustanny dwukierunkowy przepływ dóbr pośrednich, usług, osób, kapitału, informacji, pochodzących z przedsiębiorstw rozproszonych geograficznie (rys. 2).

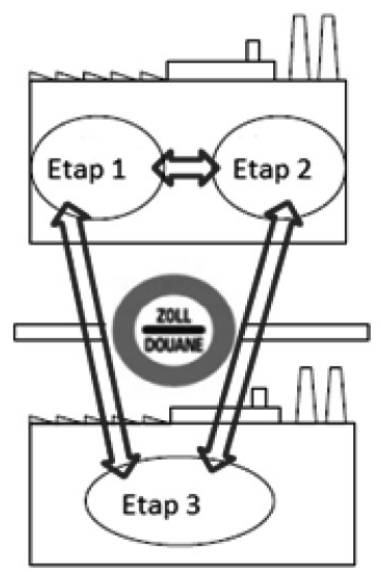

Rys. 2. Schemat ilustrujący handel międzynarodowy od drugiej połowy XX wieku

Źródło: opracowanie własne na podstawie [Baldwin 2011].

Zmienia się charakter międzynarodowego podziału pracy - poszczególne kraje mogą uczestniczyć tylko w części etapów produkcyjnych danego dobra, co powoduje, że dochodzi do tzw. specjalizacji wertykalnej. Oznacza to sytuację, w której kraje nie dzielą się na wytwarzające dobra przemysłowe i surowcowe/rolnicze, lecz podział dotyczy poszczególnych etapów łańcucha wartości - w ramach jednego rodzaju działalności (np. przemysłowej) [Geodecki, Grodzicki 2015, s. 20]. Jak podają Ambroziak i Marczewski [2014, s. 7], ,już na początku dekady 2001-2010 udział handlu pionowego w handlu światowym szacowano na ok. 25\%".

Obserwowane przyspieszenie procesów fragmentacji produkcji, oprócz przyczyn natury technologicznej, wskazanych powyżej, ma także źródła tkwiące w polityce korporacji międzynarodowych. Zaczęły one bowiem skupiać się na kluczowych kompetencjach, pozostawiając sobie te etapy łańcucha wartości, które tworzą wysoką wartość dodaną [Geodecki, Grodzicki 2015, s. 21]. Pozostałe natomiast są zlecane podmiotom zewnętrznym (outsourcing). Uznaje się, że najbardziej intratne 
są początkowe i końcowe etapy łańcuchów wartości (koncepcja „krzywej uśmiechniętej" pierwotnie wykorzystana przez założyciela Acera w 1992 r. dla zilustrowania problemów producentów IT w Taipei, rys. 3). Tak więc, najwięcej wartości dodanej można oczekiwać w opracowywaniu nowych koncepcji, B+R, wytwarzaniu kluczowych części i komponentów (góra łańcucha) oraz marketingu, brandingu, obsłudze klienta (dół łańcucha) [OECD 2013, s. 214]. W porównaniu z latami 70. XX wieku różnice między wartością dodaną, wytwarzaną w poszczególnych częściach łańcucha wartości, wyraźnie się powiększyły.

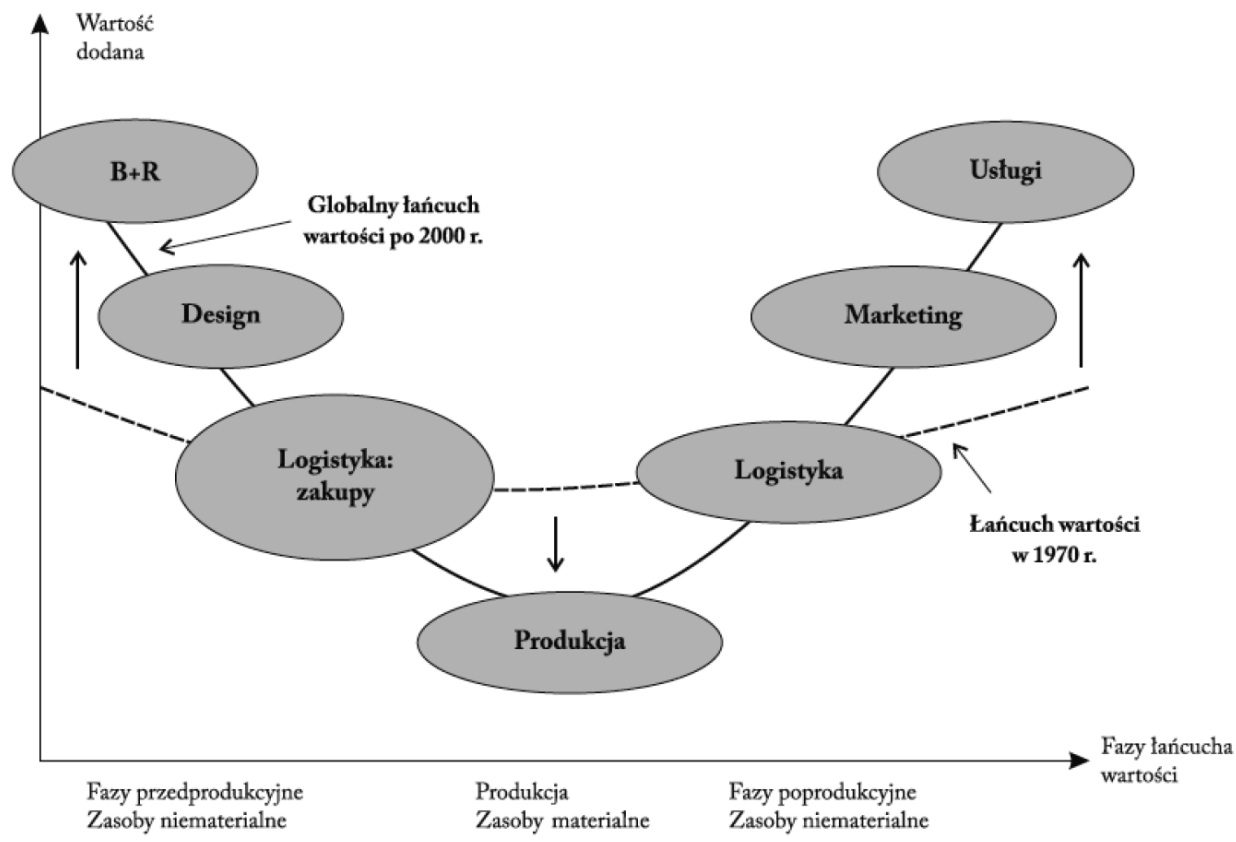

Rys. 3. Schemat ilustrujący wartość dodaną w GVC

Źródło: [Geodecki, Grodzicki 2015, s. 32].

Inną prawidłowością jest to, że procesy, które można outsourcować, zazwyczaj poddają się utowarowieniu (commoditization), a przez to tworzą relatywnie mniej wartości dodanej. Dodatkowo, jeśli dany etap produkcji cechuje się wysoką modułowością oraz ugruntowanymi standardami, jak np. w przypadku montażu elektroniki lub maszyn, to może on być wykonywany przez wiele konkurujących ze sobą firm, co dodatkowo obniża koszty. 


\section{Powiązania krajów Grupy Wyszehradzkiej w górę i dól globalnych lańcuchów wartości}

Wskutek fragmentacji produkcji eksportowane dobra i usługi zawierają nie tylko wkład krajowej wartości dodanej, ale także wsad importowy, będący składnikiem eksportowanego dobra finalnego lub półproduktu. Skala obrotów tego rodzaju sprawia, że niezwykle istotne stało się wyodrębnienie w wartości eksportu brutto krajowej i zagranicznej wartości dodanej. Do mierzenia wartości dodanej w handlu stosowane są tablice przepływów międzygałęziowych. Jedną z baz danych umożliwiającą dostęp do statystyk handlu wartością dodaną jest wspólna baza OECD i WTO Trade in Value Added (TiVA). Ostatnia dostępna edycja bazy, z grudnia 2016 r., zawiera dane na temat handlu dla 63 państw (w tym wszystkich OECD) oraz wybranych ugrupowań regionalnych w latach 1995-2011 ${ }^{13}$. W 2017 r. został opublikowany dodatkowy zbiór zawierający dane szacunkowe dla lat 2012-2014, przygotowany $\mathrm{z}$ wykorzystaniem nowcastingu ${ }^{14}$ (prognozowanie teraźniejszości ${ }^{15}$ ). Nie zawiera on jednak kompletu wskaźników dostępnych w bazie TiVA, dlatego w niniejszym opracowaniu jest wykorzystany tylko w ograniczonym zakresie.

Dzięki zgromadzonym w TiVA informacjom można policzyć wskaźnik udziału kraju w GVC. Jest on sumą zagranicznej wartości dodanej wykorzystywanej w eksporcie danego kraju (FVA - foreign value added embodied in exports) oraz jego krajowej wartości dodanej wykorzystywanej w eksporcie innych krajów (DVX domestic value added embodied in foreign exports) w relacji do wartości eksportu brutto tego kraju. Wskaźnik ten pokazuje, jaki udział w eksporcie danego kraju stanowią powiązania w ramach GVC. Są to zarówno powiązania w górę łańcucha, jak i powiązania w dół.

Dane przedstawione na rys. 4 wskazują, że państwa Grupy Wyszehradzkiej są coraz bardziej zintegrowane ze światowymi sieciami produkcyjnymi. W przypadku Czech, Słowacji i Węgier wskaźnik GVC sięgnął w 2011 r. minimum 65\%, w Polsce była to nieco niższa wartość, bo $56 \%$. Dla porównania, państwa UE-15 w tym czasie osiągnęly wynik 49\%. Wysoki poziom integracji mniejszych krajów, a więc Czech, Słowacji i Węgier, jest zjawiskiem naturalnym, wynikającym z wysokiego stopnia otwartości tych gospodarek, będącego pochodną małych krajowych rynków zbytu.

13 Oficjalne statystyki dotyczące przepływów międzygałęziowych publikowane są z dużym opóźnieniem czasowym (sięgającym w najlepszym razie dwóch, trzech lat). Konstrukcja międzynarodowych tablic międzygałęziowych wymaga ponadto zharmonizowania tablic krajowych $\mathrm{z}$ danymi o handlu dwustronnym poszczególnych krajów. Dlatego dane w bazie TiVA publikowane są z dużym opóźnieniem.

${ }^{14}$ Więcej na temat metody tego badania w: http://www.oecd.org/std/its/tiva-nowcast-methodology. pdf (23.08.2017).

${ }^{15}$ Nowcasting jest połączeniem angielskiego now (teraz) i forecasting (prognozowanie). Bańbura $\mathrm{i}$ in. podają następującą definicję nowcastingu: ,prognozowanie teraźniejszości, bardzo bliskiej przyszłości oraz bardzo niedawnej przeszłości” [Tomczyk, Doligalski 2015]. 


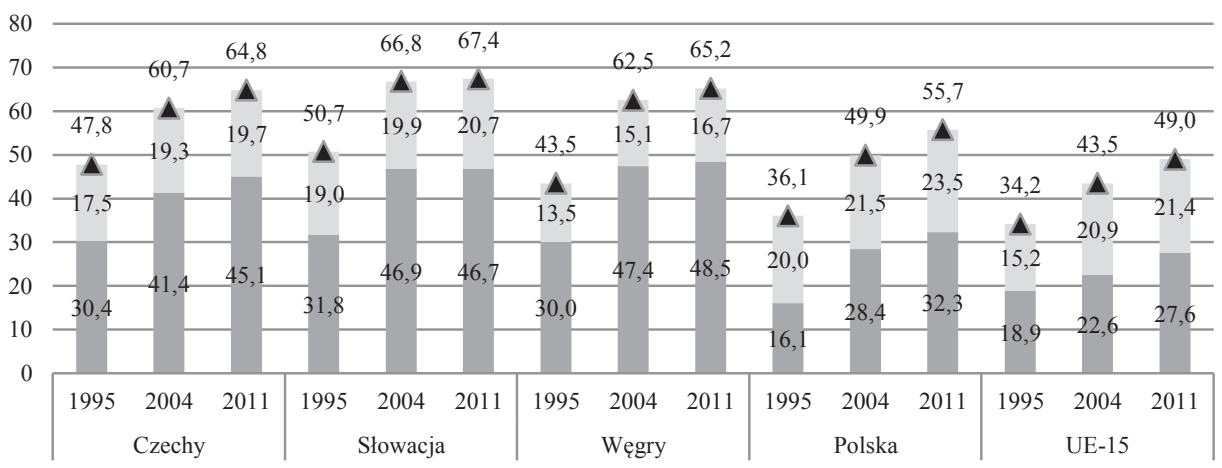

\footnotetext{
Udział krajowej wartości dodanej w eksporcie innych krajów w relacji do eksportu brutto - powiązania w dół łańcucha wartości

- Udział zagranicznej wartości dodanej w eksporcie brutto - powiązania w górę łańcucha wartości

\Suma powiązań w górę i dół łańcucha wartości - wskaźnik udziału w GVC
}

Rys. 4. Wskaźnik udziału państw V-4 oraz UE-15 w globalnych łańcuchach wartości w latach 1995-2011

Źródło: opracowanie własne na podstawie [OECD/WTO 2016].

W analizowanym okresie w Polsce nastąpiło podwojenie powiązań w górę (wzrost udziału importu półproduktów zawartych w eksporcie z Polski dóbr pośrednich lub finalnych z 16\% do 32\% eksportu ogółem) i umiarkowany wzrost powiązań w dół łańcucha (wzrost zawartości krajowej wartości dodanej w eksporcie innych krajów z 20\% do 23\% eksportu ogółem). Ten sam kierunek zmian, jednak ze znacznie mniejszą dynamiką, wystąpił w pozostałych krajach Grupy. We wszystkich występuje wyraźna przewaga powiązań w górę nad powiązaniami w dół łańcucha. W Polsce, podobnie jak w UE-15, przewaga udziału zagranicznej wartości dodanej w eksporcie jest stosunkowo niska.

Uzyskane wyniki wskazują, że: po pierwsze, kraje V-4 są stosunkowo bardziej atrakcyjne jako miejsce przetwarzania półproduktów niż jako producenci i eksporterzy dóbr pośrednich wykorzystywanych następnie w produkcji i eksportowanych przez inne kraje; po drugie, rosnący udział zagranicznej wartości dodanej w eksporcie wskazuje na wzrost importochłonności wywozu. Jest to wynikiem pogłębiającej się integracji tych gospodarek z gospodarką światową. Aby wytwarzać atrakcyjne dobra, znajdujące zbyt na wymagających rynkach międzynarodowych, konieczny jest import przynajmniej części odpowiednich półproduktów [Ścigała 2013]; po trzecie, biorąc pod uwagę fakt, że eksport brutto jest sumą zagranicznej i krajowej wartości dodanej - następuje systematyczny spadek krajowej wartości dodanej w eksporcie krajów V-4 (rys. 5). Na tle pozostałych krajów Grupy udział krajowej wartości dodanej w polskim eksporcie jest stosunkowo wysoki i w 2014 r. wyniósł $67 \%$, podczas gdy w reszcie krajów wynosił ok. $53 \%$. 


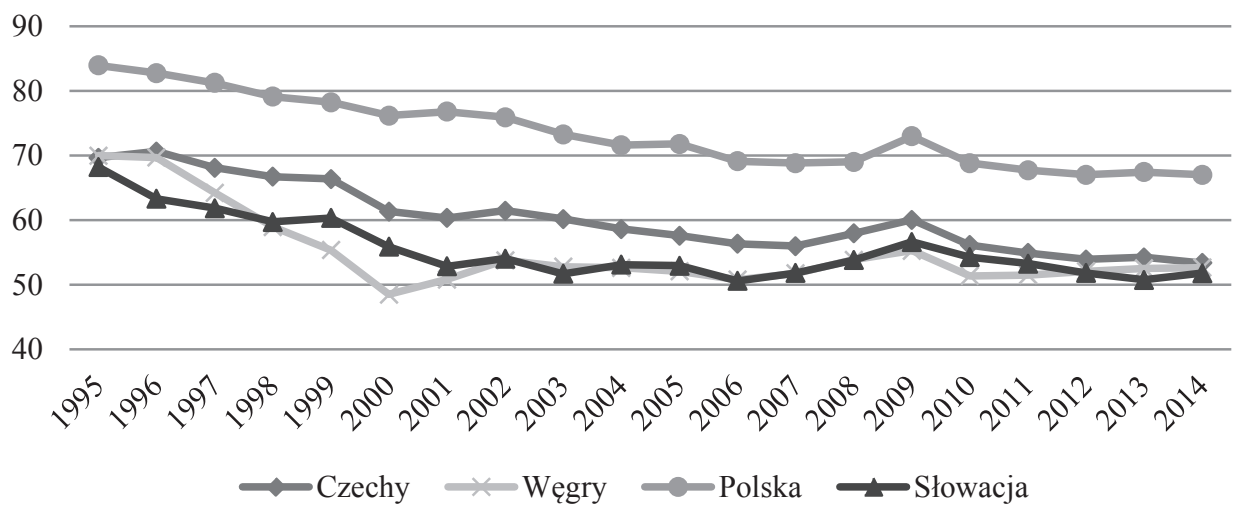

Rys. 5. Wskaźnik udziału krajowej wartości dodanej w eksporcie brutto państw V-4 w latach 1995-2014 (w \%)

Źródło: opracowanie własne na podstawie [OECD/WTO 2016 oraz OECD/WTO 2017].

Oczywiście, chodzi nie tyle o udział tej wartości w eksporcie brutto ogółem, ile o uczestnictwo w tych etapach produkcji, które są najbardziej wartościowe (czyli, zgodnie z koncepcją „krzywej uśmiechu”, znajdują się na początku lub na końcu łańcucha). W krajach Grupy Wyszehradzkiej dominuje jednak produkcja w środkowych częściach łańcucha, dająca relatywnie niewiele wartości dodanej [Ambroziak 2015, s. 279]. Ponadto systematyczny spadek udziału krajowej wartości dodanej w eksporcie świadczy o istotnych niedoskonałościach strukturalnych sektora eksportowego [Ścigała 2013].

\section{Udział zagranicznej wartości dodanej w eksporcie brutto krajów Grupy Wyszehradzkiej według grup towarowych}

Najwyższa fragmentacja procesów produkcji w krajach V-4 dotyczy czterech grup towarowych: maszyn i urządzeń, urządzeń elektrycznych i optycznych, środków transportu oraz pozostałych produktów przemysłowych (tabela 1).

W 2014 r. na Słowacji 60\% eksportu brutto maszyn i urządzeń składało się z importowanych wcześniej do tej branży produktów. W Czechach i na Węgrzech wskaźnik ten osiągnął ok. 50\%, w Polsce zaś ok. 42\%. W eksporcie urządzeń elektrycznych i optycznych najwyższy udział wsadu zagranicznego w eksporcie również odnotowano na Słowacji (55\%), następnie na Węgrzech (51\%) i w Czechach (49\%). W Polsce udział ten sięgnął $42 \%$. Najwyższy poziom zagranicznej wartości dodanej w eksporcie wszystkich czterech krajów wystąpił w eksporcie środków transportu (z wyjątkiem Polski wyniki były powyżej $60 \%$, na Węgrzech było to prawie $70 \%$ ). Słowacja i Węgry uzyskały najwyższy udział zagranicznej wartości dodanej w przypadku pozostałych produktów przemysłowych (powyżej 60\%). W przypad- 
ku Czech, Węgier (i w mniejszym stopniu Polski) ponadprzeciętna fragmentacja (powyżej wyników dla wszystkich branż ogółem) dotyczy także branży tekstylnej, odzieży i obuwia. Czechy i Polska wykazały się także stosunkowo wysokim udziałem zagranicznej wartości dodanej w eksporcie drewna i papieru oraz chemikaliów i materiałów niemetalicznych.

Tabela 1. Udział zagranicznej wartości dodanej w eksporcie brutto w branżach przemysłu w państwach V-4, w procentach, w 1995 i 2014 r.

\begin{tabular}{|l|c|c|c|c|c|c|c|c|}
\hline \multirow{2}{*}{\multicolumn{1}{|c|}{ Wyszczególnienie }} & \multicolumn{2}{c|}{ Czechy } & \multicolumn{2}{c|}{ Polska } & \multicolumn{2}{c|}{ Słowacja } & \multicolumn{2}{c|}{ Węgry } \\
\cline { 2 - 10 } & 1995 & 2014 & 1995 & 2014 & 1995 & 2014 & 1995 & 2014 \\
\hline Ogólem & $\mathbf{3 0 , 4}$ & $\mathbf{4 6 , 6}$ & $\mathbf{1 6 , 1}$ & $\mathbf{3 3 , 0}$ & $\mathbf{3 1 , 8}$ & $\mathbf{4 8 , 2}$ & $\mathbf{3 0 , 0}$ & $\mathbf{4 7 , 3}$ \\
\hline $\begin{array}{l}\text { Rolnictwo, rybołówstwo, } \\
\text { leśnictwo i łowiectwo }\end{array}$ & 20,9 & 35,1 & 11,5 & 23,1 & 20,1 & 21,3 & 18,2 & 28,1 \\
\hline Górnictwo i kopalnictwo & 23,2 & 29,9 & 12,7 & 21,1 & 23,9 & 28,7 & 25,3 & 32,6 \\
\hline Żywność, napoje i tytoń & 28,5 & 43,3 & 12,9 & 26,4 & 24,1 & 33,4 & 24,3 & 37,6 \\
\hline Tekstylia, odzież i obuwie & 41,3 & 52,3 & 17,2 & 37,0 & 27,8 & 37,9 & 37,6 & 56,7 \\
\hline Drewno, papier & 28,8 & 48,0 & 14,7 & 39,8 & 26,2 & 47,5 & 30,4 & 46,2 \\
\hline $\begin{array}{l}\text { Chemikalia i minerały nieme- } \\
\text { taliczne }\end{array}$ & 37,7 & 46,4 & 19,1 & 36,9 & 36,8 & 44,0 & 33,6 & 44,9 \\
\hline $\begin{array}{l}\text { Metale podstawowe i produk- } \\
\text { ty metalowe }\end{array}$ & 33,8 & 39,8 & 21,0 & 31,1 & 43,2 & 32,1 & 41,9 & 40,8 \\
\hline Maszyny i urządzenia & 34,8 & 50,0 & 20,3 & 41,7 & 35,9 & 60,0 & 39,2 & 52,0 \\
\hline $\begin{array}{l}\text { Urządzenia elektryczne } \\
\text { i optyczne }\end{array}$ & 43,6 & 48,6 & 22,9 & 41,7 & 44,5 & 55,0 & 49,4 & 51,0 \\
\hline Środki transportu & 51,2 & 63,1 & 24,1 & 49,6 & 55,7 & 60,4 & 56,8 & 68,2 \\
\hline $\begin{array}{l}\text { Pozostałe produkty przemy- } \\
\text { słowe, meble, recycling }\end{array}$ & 30,9 & 56,2 & 17,0 & 47,8 & 28,9 & 63,0 & 30,1 & 63,1 \\
\hline
\end{tabular}

Źródło: opracowanie własne na podstawie [OECD/WTO 2016 oraz OECD/WTO 2017].

Analiza tendencji zmian udziału zagranicznej wartości dodanej w eksporcie brutto w latach 1995-2014 wskazuje, że największy wzrost we wszystkich krajach wystąpił w grupie pozostałych produktów przemysłowych (od ok. 25 do 34 p.p.). W Czechach, Polsce i na Słowacji wysoki wzrost udziału zagranicznej wartości dodanej wystąpił także w przypadku eksportu maszyn i urządzeń (odpowiednio o ok. 15, 21 i 24 p.p.) oraz drewna i papieru (o ok. 19, 25 i 21 p.p.). Na Węgrzech i w Polsce nastąpił prawie 20-punktowy wzrost w przypadku tekstyliów, odzieży i obuwia. Fragmentacja nie dotyczy więc tylko branż wyżej zaawansowanych technicznie, ale w coraz większym stopniu również branż o niższym poziomie zaawansowania technicznego i opartych na surowcach. W najmniejszym stopniu procesy fragmentacji dotyczą rolnictwa, rybołówstwa, leśnictwa i łowiectwa oraz górnictwa i kopalnictwa (szerzej [Białowąs 2015]). 


\section{Wartość dodana Czech, Węgier i Słowacji w eksporcie Polski}

Przedstawione dane świadczą o coraz większym zaangażowaniu państw V-4 w globalne łańcuchy wartości. Na ile jednak tendencja ta przekłada się na wzrost więzi handlowych między nimi? I czy jest szansa, by „handel wyprzedził banderę”?

Analiza udziału wartości dodanej pochodzącej z Polski w łącznym eksporcie Czech, Słowacji i Węgier wskazuje na niewielki, ale rosnący w czasie udział Polski w handlu tych krajów. W 1995 r. udział polskiej wartości dodanej w eksporcie ogółem tych państw wynosił 0,8\%, natomiast w 2011 r. wzrósł do 2,2\% (por. rys. 6). Bardzo podobna sytuacja miała miejsce w wybranych do analizy branżach przemysłu, a więc w tych, w których zaobserwowano najwyższy udział zagranicznej wartości dodanej w eksporcie brutto.

Udział wartości dodanej z Polski w eksporcie Czech, Słowacji i Węgier

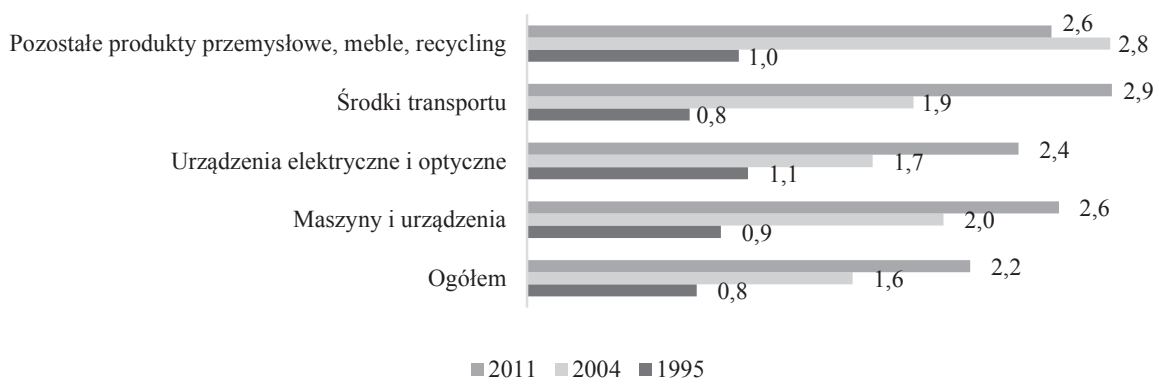

Udział wartości dodanej z Czech, Słowacji i Węgier w eksporcie Polski

Pozostałe produkty przemysłowe, meble, recycling

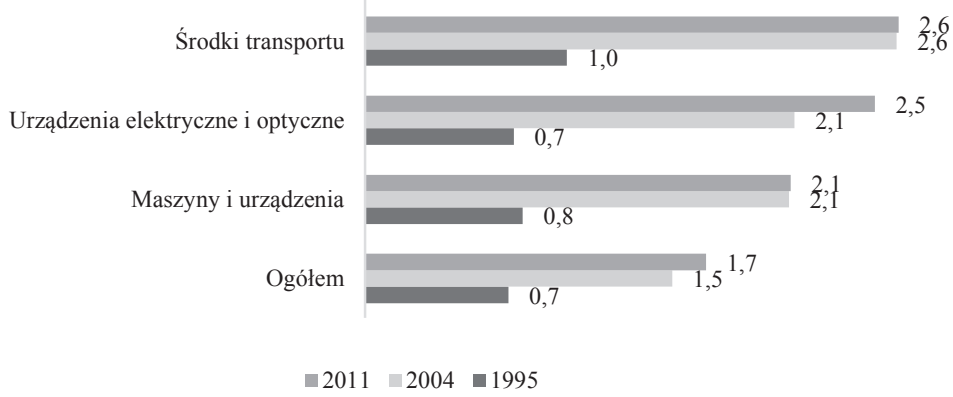

Rys. 6. Udział wartości dodanej z krajów V-4 w ich eksporcie brutto ogółem i wybranych branż przemysłu w latach 1995-2011 (w \%)

Źródło: opracowanie własne na podstawie [OECD/WTO 2016]. 
Mniejszy jest udział wartości dodanej pochodzącej z Czech, Słowacji i Węgier w polskim eksporcie. W $2011 \mathrm{r}$. wynosił on 1,7\% w eksporcie ogółem. Mimo iż w punkcie wyjścia, a więc w 1995 r., wskaźniki wzajemnych udziałów w eksporcie krajów V-4 w poszczególnych branżach były podobne (poniżej 1\%), to zauważyć można, że wyższa była dynamika wzrostu udziału Polski w eksporcie pozostałych krajów V-4 niż odwrotnie ${ }^{16}$.

\section{Zakończenie}

Kraje Grupy Wyszehradzkiej łączy w zasadzie tylko położenie geograficzne. Nie ma między nimi bliskości historycznej, kulturowej ani gospodarczej. Różnią się prowadzoną polityką zagraniczną.

Tym, co w ostatnich latach łączy Polskę, Czechy, Słowację i Węgry, jest ich rosnąca integracja ze światowymi sieciami produkcyjnymi. Wskazują na to wskaźniki udziału krajów V-4 w globalnych łańcuchach wartości. Najbardziej umiędzynarodowione procesy produkcyjne występują w czterech grupach towarowych: maszyny i urządzenia, urządzenia elektryczne i optyczne, środki transportu oraz pozostałe produkty przemysłowe, meble, recycling.

Sformułowane wcześniej stwierdzenie, że być może wytworzeniu rzeczywistych więzi Grupy będą sprzyjać więzi handlowe, znajduje częściowe odzwierciedlenie w danych statystycznych dotyczących wzajemnego zaangażowania wartości dodanej pochodzącej z poszczególnych krajów Grupy w ich eksporcie. Wprawdzie poziom tych powiązań jest wciąż niski, jednak występuje wyraźna tendencja rosnąca. W szczególności dotyczy to wzrostu udziału wartości dodanej z Polski w eksporcie Czech, Słowacji i Węgier.

\section{Literatura}

Ambroziak Ł., 2015, Wplyw fragmentaryzacji produkcji na polski handel zagraniczny maszynami i urzadzeniami, [w:] Chojna J. (red.), Inwestycje zagraniczne w Polsce, IBRKK, Warszawa.

Ambroziak Ł., Marczewski K., 2014, Zmiany w handlu zagranicznym Polski w kategoriach wartości dodanej, Unia Europejska.pl, nr 6 (229).

Ash T.G., 1999, The puzzle of Central Europe, The New York Review of Books, March 18, http://www. nybooks.com/articles/1999/03/18/the-puzzle-of-central-europe/ (10.08.2017).

Baldwin R., 2011, Trade and industrialisation after globalisation's 2nd unbundling: How building and joining a supply chain are different and why it matters, NBER Working Paper Series, No. 17716, DOI: $10.3386 / \mathrm{w} 17716$.

Baru S., 2012, A New Era of Geo-economics: Assessing the Interplay of Economic and Political Risk, IISS Seminar, 23-25 March.

\footnotetext{
${ }^{16}$ Wymogi dotyczące objętości opracowania nie pozwalają na dokonanie analizy powiązań między kolejnymi członkami Grupy.
} 
Białowąs T., 2015, Wptyw międzynarodowej fragmentaryzacji procesów produkcji na zmiany strukturalne w handlu krajów Europy Środkowej, Studia i Prace Wydziału Nauk Ekonomicznych i Zarządzania, t. 1, nr 41.

Broadberry S., Klein A., 2011, Aggregate And Per Capita GDP in Europe, 1870-2000: Continental, Regional And National Data With Changing Boundaries, http://dev3.cepr.org/meets/wkcn/1/1699/ papers/Broadberry_Klein.pdf(19.08.2017).

Caves R.E., 2002, International corporations. The Industrial economics of foreign investment, [w:] Rugman A.M. (ed.), International Business: Theory of the Multinational Enterprise. Critical Perspectives on Business and Management, Routledge, London - New York, vol. I.

CIA The World Factbook, https://www.cia.gov/library/publications/the-world-factbook/fields/2122. html (19.08.2017).

Engelberg S., 1991, Three Eastern European Leaders Confer, Gingerly, The New York Times, February 17, http:/www.nytimes.com/1991/02/17/world/three-eastern-european-leaders-confer-gingerly. html (5.08.2017).

Geodecki T., Grodzicki M.J., 2015, Jak awansować w światowej lidze gospodarczej? Kraje Europy Środkowo-Wschodniej w globalnych tańcuchach wartości, Zarządzanie Publiczne, nr 3(33).

Gereffi G., 2005, The global economy: Organization, governance, and development, [w:] Smelser N.J., Swedberg R. (eds.), The Handbook of Economic Sociology, Princeton University Press, Princeton.

Grossman G.M., Rossi-Hansberg E., 2006, The rise of offshoring: It's not wine for cloth anymore, Proceedings - Economic Policy Symposium - Jackson Hole, Federal Reserve Bank of Kansas City.

Jones R.W., Kierzkowski H., 2001, A framework for fragmentation, [w:] Arndt S.W., Kierzkowski H. (eds.), Fragmentation. New Production Patterns in the World Economy, Oxford University Press, Oxford.

Kelly G., 1955, The Psychology of Personal Constructs, vol. I, II, Norton, New York.

Klus A., 2015, What makes the Visegrad Group so geopolitically fragile?, New Eastern Europe, 5 June, http://www.neweasterneurope.eu/articles-and-commentary/1617-what-makes-the-visegrad- group-so-geopolitically-fragile (5.08.2017).

Krawczyk A., 2015, Stowacja księdza prezydenta (Jozef Tiso 1887-1947), Wydawnictwo Znak, Kraków.

OECD, 2013, Interconnected Economies, Benefitting from Global Value Chains, Paris.

OECD/WTO, 2016, Trade in Value Added (TiVA) - December 2016, https://stats.oecd.org/index.aspx?queryid=75537 (25.07.2017).

OECD/WTO, 2017, TiVA Nowcast Estimates, https://stats.oecd.org/index.aspx?queryid=75537 (25.07.2017).

Pollins B.M., 1989, Does trade still follow the flag?, The American Political Science Review, vol. 83, no. 2.

Schmidt A., 2016, Friends forever? The role of the Visegrad Group and European integration, Politics in Central Europe, vol. 12, no. 3.

Ścigała D., 2013, Pozycja gospodarki polskiej w ramach globalnych tańcuchów wartości, IX Kongres Ekonomistów Polskich.

Tomczyk E., Doligalski T., 2015, Nowcasting, czyli prognozowanie teraźniejszości, http://www.valuecomesfirst.pl/nowcasting/ (10.07.2017).

Van Bergeijk P.A.G., 2009, Economic Diplomacy and the Geography of International Trade, Edward Elgar Publishing Limited, Cheltenham. 